\title{
Short communication: Effects of supplementing diets of Holsteins with copper, zinc, and manganese on blood neutrophil function
}

\author{
A. M. Dietz, W. P. Weiss, M. J. Faulkner, and J. S. Hogan ${ }^{1}$ \\ Ohio Agricultural Research and Development Center, The Ohio State University, Wooster 44691
}

\begin{abstract}
The effects of supplementing diets with sulfate or glycinate $\mathrm{Cu}, \mathrm{Zn}$, and $\mathrm{Mn}$ on blood neutrophil function were examined in 27 late-lactation Holstein cows having a mean ( \pm standard deviation) days in milk at time of neutrophil assays of $216 \pm 31 \mathrm{~d}$. Cows were assigned to 9 blocks of 3 and were grouped by parity, milk production, and days in milk. Cows within each block were randomly assigned to 1 of 3 treatments: (1) control diet devoid of supplemental $\mathrm{Cu}, \mathrm{Zn}$, and $\mathrm{Mn}$; (2) diet supplemented with $\mathrm{Cu}, \mathrm{Zn}$, and $\mathrm{Mn}$ via sulfates; and (3) diet supplemented with $\mathrm{Cu}, \mathrm{Zn}$, and $\mathrm{Mn}$ via glycinate form. All cows were initially fed a control total mixed ration with basal mineral concentrations of $8 \mathrm{mg} / \mathrm{kg}$ of $\mathrm{Cu}, 35 \mathrm{mg} / \mathrm{kg}$ of $\mathrm{Zn}$, and $35 \mathrm{mg} / \mathrm{kg}$ of $\mathrm{Mn}$ for $30 \mathrm{~d}$. During the treatment period, cows fed diets with mineral supplementation via sulfates or glycinate forms had target total dry matter dietary concentrations of $18 \mathrm{mg} / \mathrm{kg}$ of $\mathrm{Cu}, 60 \mathrm{mg} / \mathrm{kg}$ of $\mathrm{Zn}$, and $60 \mathrm{mg} /$ $\mathrm{kg}$ of $\mathrm{Mn}$ for $30 \mathrm{~d}$. Control cows were fed the control diet devoid of supplemental minerals for an additional $30 \mathrm{~d}$. In vitro neutrophil functions were measured after $30 \mathrm{~d}$ on experimental or control diets. Percentage of neutrophils phagocytizing, intracellular kill, and phagocytic index did not differ among treatments. Serum concentrations of $\mathrm{Cu}, \mathrm{Zn}$, and $\mathrm{Mn}$ were also not affected by dietary treatment after $30 \mathrm{~d}$. Results from this study demonstrated that dietary $\mathrm{Cu}, \mathrm{Zn}$, and $\mathrm{Mn}$ supplemented either as sulfates or glycinate form for $30 \mathrm{~d}$ had no effect on either in vitro blood neutrophil function or serum concentrations of $\mathrm{Cu}, \mathrm{Zn}$, and $\mathrm{Mn}$ in late-lactation Holstein cows.
\end{abstract}

Key words: copper, zinc, manganese, neutrophils

\section{Short Communication}

Many factors contribute to the functional status of bovine neutrophils that ultimately affect mammary

Received July 27, 2016.

Accepted November 21, 2016.

${ }^{1}$ Corresponding author: hogan.4@osu.edu gland host defenses and prevention of mastitis. Nutritional status of the cow influences host defenses and effects the duration and severity of disease (Scaletti et al., 2003; Goff, 2006; Heinrichs et al., 2009). Microminerals, such as $\mathrm{Cu}, \mathrm{Zn}$, and $\mathrm{Mn}$, have been shown to be beneficial in improving udder health by reducing SCC and decreasing the incidence of mastitis in the periparturient and early lactation periods (Scaletti et al., 2003; Siciliano-Jones et al., 2008). Copper, Zn, and Mn are essential for the functionality of many enzymes and structural and cellular proteins (Nocek et al., 2006). The essential nature of these minerals in the antioxidant role of enzymes mediating phagocytosis and killing of bacteria by bovine neutrophils was recently reviewed by Overton and Yasui (2014). Traditionally, microminerals have been supplemented via sulfates; however, organic supplementation has been reported to increase bioavailability and absorption of microminerals in the gut (Andrieu, 2008). Enhancing mineral absorption may have a positive effect on neutrophil function due to increased accessibility to minerals in blood. Studies have shown that organic supplementation of microminerals has been associated with improvements in milk yield, clinical udder score, and Escherichia coli counts in milk compared with inorganic and unsupplemented groups following an E. coli challenge in early-lactation animals (Scaletti and Harmon, 2012). Although the influence of dietary supplementation of various essential minerals on host defenses and mammary health in early-lactation cows have been reported, little information is available on the benefits of supplementing dietary inorganic and organic sources of minerals on health parameters, including neutrophil function, in late-lactation cows. Therefore, the objective of the current study was to examine the effects of sulfate or glycinate dietary supplementation of $\mathrm{Cu}, \mathrm{Zn}$, and $\mathrm{Mn}$ in late-lactation cows on in vitro bovine neutrophil phagocytosis and intracellular kill.

Twenty-seven late-lactation Holstein cows in the Ohio Agriculture Research and Development Center Krauss Dairy Herd were used to measure the effects of $\mathrm{Cu}, \mathrm{Zn}$, and $\mathrm{Mn}$ supplementation on bovine neutrophil function. All procedures using animals were approved through The Ohio State Institutional Animal 
Use and Care Committee (Columbus, OH), Animal Use Protocol: 2014A00000059. Cows were assigned to 9 blocks of 3 based on parity, milk production, and DIM. Four blocks were composed of primiparous cows, and 5 blocks were composed of multiparous cows. Average $( \pm \mathrm{SD})$ milk production was $31.4 \pm 6.3 \mathrm{~kg}$ during the pretreatment period and DIM was $216 \pm 31 \mathrm{~d}$ at time of neutrophil assays. Blocks of cows were moved to the pretreatment pen on alternating days over an 18-d period so that each block was sampled on a separate day for neutrophil assays corresponding to d 31 on dietary treatments. Cows were fed a TMR once daily through the pretreatment and treatment periods with a target of 3 to $5 \%$ refusal. During the pretreatment period, all cows were fed a diet without supplementation with a commercial source of $\mathrm{Cu}, \mathrm{Zn}$, and $\mathrm{Mn}$. Dietary concentrations of $\mathrm{Cu}, \mathrm{Zn}$, and $\mathrm{Mn}$ were 8.0,35.0, and 35.0 $\mathrm{mg} / \mathrm{kg}$ of dietary DM, respectively, for $30 \mathrm{~d}$ and cows were housed in freestalls. After this period, cows were moved into tiestalls and placed on 1 of the 3 treatment diets for an additional $30 \mathrm{~d}$ (Table 1). Cows within blocks were randomly assigned to 1 of 3 treatments by pulling slips of paper out of a container: (1) devoid of supplemental $\mathrm{Cu}, \mathrm{Zn}$, and $\mathrm{Mn}$; (2) supplemented with $\mathrm{Cu}, \mathrm{Zn}$, and $\mathrm{Mn}$ via sulfates; and (3) supplemented with $\mathrm{Cu}, \mathrm{Zn}$, and $\mathrm{Mn}$ via glycinate form (B-Traxim, Pancosma, Geneva, Switzerland). The unsupplemented treatment cows, which served as the control, remained on basal control $\mathrm{Cu}, \mathrm{Zn}$, and $\mathrm{Mn}$ dietary concentrations. The sulfate and glycinate treatments were supplemented with target total dietary concentrations of $18.0,60.0$, and $60.0 \mathrm{mg} / \mathrm{kg}$ of $\mathrm{DM}$ of $\mathrm{Cu}, \mathrm{Zn}$, and $\mathrm{Mn}$, respectively. Details of ingredient composition of diets and nutrient composition of diets and forages supplied by diets are in Table 2. Feed component samples were collected weekly and DM $\left(100^{\circ} \mathrm{C}\right.$ oven for $\left.24 \mathrm{~h}\right)$ was calculated and recorded. Feed samples were kept frozen at $-20^{\circ} \mathrm{C}$ until the trial was complete. Once the trial was completed, composite samples were prepared for each feed component: corn silage, alfalfa silage, dry hay, and 3 treatment grain mixes. Composite samples were composed of 2 to 4 consecutive sample dates and sent to a commercial analytic laboratory (Cumberland Valley Analytical Services; Hagerstown, MD) for analyses.

Blood $(50 \mathrm{~mL})$ was collected from each animal in a block on the same day via jugular vein with a 16-gauge, 1.5-in. needle. Neutrophils were isolated according to Carlson and Kaneko (1973). Blood was collected in sterile 60-mL syringes (BD Luer-Lok, Becton Dickinson Microbiology Systems, Cockeysville, MD) containing 5 $\mathrm{mL}$ of EDTA anticoagulant $(0.7 \% \mathrm{NaCl}, 1.5 \%$ EDTA disodium salt: dehydrate, $0.0132 M \mathrm{KH}_{2} \mathrm{PO}_{4}$ and 0.0132 $M \mathrm{Na}_{2} \mathrm{HPO}_{4}$; adjusted to $\mathrm{pH}$ 6.6). Forty milliliters of blood was dispensed into $50-\mathrm{mL}$ conical bottom centrifuge tubes (Corning Inc., Corning, NY) and centrifuged (Sorvall RT7, RTH-750 rotor; Newtown, CT) for 45 min at $4^{\circ} \mathrm{C}$ and $1,294 \times g$. The plasma, buffy coat, and upper $2 \mathrm{~mL}$ of red blood cells were discarded, leaving approximately $8 \mathrm{~mL}$ of packed cells remaining. Remaining red blood cells were lysed by adding $30 \mathrm{~mL}$ of 0.03 $M \mathrm{NaCl}$ to the tube and mixing for $90 \mathrm{~s}$ by hand. Eight milliliters of $0.63 \mathrm{M} \mathrm{NaCl}$ was added and mixed to bring saline solution back to equilibrium. After lysis, cells were centrifuged for $15 \mathrm{~min}$ at $4^{\circ} \mathrm{C}$ and $748 \times \mathrm{g}$. The supernatant was removed, neutrophil pellet was washed with $5 \mathrm{~mL}$ of Hanks' Balanced Salt Solution (HBSS; modified, without phenol red and sodium bicarbonate; Sigma-Aldrich, St. Louis, MO) and then centrifuged again for $15 \mathrm{~min}$ at $4^{\circ} \mathrm{C}$ and $748 \times g$. Again, the supernatant was removed and $1 \mathrm{~mL}$ of HBSS was added to resuspend the pellet. Viability of isolated cells was measured using a trypan blue exclusion procedure. Briefly, 0.05\% trypan blue (Sigma-Aldrich) solution was added to $10 \mu \mathrm{L}$ of neutrophil suspension, and 100 cells mounted on a hemocytometer (Bright-line hemocytometer; Reichert, Buffalo, NY) were counted at

Table 1. Ingredient composition of the $\operatorname{diet}^{1}$ (\% of DM) for cows fed unsupplemented control diets or sulfate or glycinate $\mathrm{Cu}-, \mathrm{Zn}-$, and $\mathrm{Mn}-$ supplemented diets for $30 \mathrm{~d}$

\begin{tabular}{|c|c|c|c|}
\hline Ingredient & Control & Sulfate & Glycinate \\
\hline Corn silage & 29.0 & 29.0 & 29.0 \\
\hline Alfalfa silage & 29.0 & 29.0 & 29.0 \\
\hline Alfalfa hay & 5.0 & 5.0 & 5.0 \\
\hline Corn dried distillers grains & 9.2 & 9.2 & 9.2 \\
\hline Ground corn & 19.2 & 19.2 & 19.1 \\
\hline Soybean meal, $48 \%$ CP & 6.5 & 6.5 & 6.5 \\
\hline Animal/vegetable fat & 0.36 & 0.36 & 0.36 \\
\hline Limestone & 0.65 & 0.65 & 0.65 \\
\hline Magnesium oxide & 0.05 & 0.05 & 0.05 \\
\hline Iodized salt & 0.42 & 0.42 & 0.42 \\
\hline Selenium premix $^{2}$ & 0.14 & 0.14 & 0.14 \\
\hline Vitamin $\operatorname{mix}^{3}$ & 0.46 & 0.18 & 0.18 \\
\hline $\mathrm{Cu}$ sulfate & - & 0.003 & - \\
\hline Zn sulfate & - & 0.006 & - \\
\hline Mn sulfate & - & 0.006 & - \\
\hline Glycinate $\mathrm{Cu}^{4}$ & - & - & 0.003 \\
\hline Glycinate $\mathrm{Zn}^{4}$ & - & - & 0.009 \\
\hline Glycinate $\mathrm{Mn}^{4}$ & - & - & 0.010 \\
\hline
\end{tabular}

${ }^{1}$ The control diet was fed to all cows for $30 \mathrm{~d}$ before the experiment and to the control group during the $30-\mathrm{d}$ experiment. The sulfate and organic treatments provided all supplemental $\mathrm{Cu}, \mathrm{Zn}$, and $\mathrm{Mn}$ as either sulfate or as glycinates and were fed only during the experimental phase.

${ }^{2}$ Sodium selenate, $200 \mathrm{mg} / \mathrm{kg}$.

${ }^{3}$ Contained $735 \mathrm{kIU}$ of vitamin $\mathrm{A} / \mathrm{kg}, 270 \mathrm{kIU}$ of vitamin $\mathrm{D} / \mathrm{kg}$, 4,400 IU of vitamin E, and $135 \mathrm{mg}$ of biotin (Rovimix Biotin, DSM Nutritional Products, Heerlen, the Netherlands) per kilogram.

${ }^{4}$ B-Traxim 2C (Pancosma S. A., Geneva, Switzerland). The products contained 270,000, 260,000, and 220,000 $\mathrm{mg}$ of $\mathrm{Cu}, \mathrm{Zn}$, and $\mathrm{Mn} / \mathrm{kg}$, respectively. 
Table 2. Nutrient composition of diet and ingredients for cows fed unsupplemented control diets or sulfate or glycinate Cu-, Zn-, and Mnsupplemented diets for $30 \mathrm{~d}$

\begin{tabular}{|c|c|c|c|c|c|c|c|c|c|}
\hline \multirow[b]{2}{*}{ Item } & \multicolumn{3}{|c|}{ Total } & \multicolumn{6}{|c|}{ Component $^{1}$} \\
\hline & Control & $\begin{array}{c}\text { Sulfate } \\
\text { supplemented }\end{array}$ & $\begin{array}{c}\text { Glycinate } \\
\text { supplemented }\end{array}$ & $\begin{array}{l}\text { Corn } \\
\text { silage }\end{array}$ & $\begin{array}{l}\text { Alfalfa } \\
\text { silage }\end{array}$ & $\begin{array}{c}\text { Alfalfa } \\
\text { hay }\end{array}$ & $\begin{array}{l}\text { Grain mix } \\
\text { sulfate }\end{array}$ & $\begin{array}{l}\text { Grain mix } \\
\text { control }\end{array}$ & $\begin{array}{l}\text { Grain mix } \\
\text { glycinate }\end{array}$ \\
\hline DM, \% & 59.3 & 59.0 & 59.7 & 36.7 & 40.6 & 86.4 & 87.2 & 88.0 & 89.0 \\
\hline OM, \% & 92.4 & 92.3 & 92.2 & 95.8 & 88.8 & 89.7 & 92.8 & 92.9 & 92.5 \\
\hline NDF, $\%$ & 28.4 & 28.3 & 28.2 & 34.6 & 39.0 & 38.0 & 13.6 & 14.0 & 13.4 \\
\hline $\mathrm{CP}, \%$ & 17.0 & 17.3 & 17.3 & 6.7 & 20.9 & 19.2 & 22.4 & 21.7 & 22.6 \\
\hline $\mathrm{Mg}, \%$ & 0.29 & 0.28 & 0.29 & 0.17 & 0.33 & 0.31 & 0.33 & 0.36 & 0.35 \\
\hline $\mathrm{K}, \%$ & 1.89 & 1.88 & 1.90 & 1.25 & 3.43 & 2.52 & 1.07 & 1.10 & 1.12 \\
\hline S, \% & 0.28 & 0.28 & 0.28 & 0.11 & 0.30 & 0.25 & 0.40 & 0.40 & 0.41 \\
\hline $\mathrm{Na}, \%$ & 0.24 & 0.22 & 0.25 & 0.01 & 0.06 & 0.08 & 0.54 & 0.58 & 0.60 \\
\hline $\mathrm{Fe}, \mathrm{mg} / \mathrm{kg}$ & 225 & 222 & 224 & 99 & 504 & 169 & 105 & 112 & 109 \\
\hline $\mathrm{Cu}, \mathrm{mg} / \mathrm{kg}$ & 9 & 17 & 20 & 6 & 13 & 9 & 29 & 8 & 37 \\
\hline $\mathrm{Zn}, \mathrm{mg} / \mathrm{kg}$ & 41 & 59 & 66 & 33 & 34 & 29 & 104 & 53 & 121 \\
\hline
\end{tabular}

${ }^{1}$ All ingredients other than corn silage, alfalfa silage, and alfalfa hay were mixed and analyzed as a grain mix.

$40 \times$ magnification. Blue and clear cells were counted as dead and live, respectively. Total cell count was determined by counting all cells in 4 fields on a hemocytometer. A differential stain (Protocol HEMA 3 Stain Set; Fisher Scientific Company LLC, Middletown, VA) was completed to determine percentage of neutrophils in the preparation. This was measured by counting first 100 cells observed. The number of viable neutrophils was determined by total number of cells multiplied by viability and percentage of neutrophils [(total cells $) \times$ (viability) $\times(\%$ neutrophil $)]$. Cell preparations averaged $( \pm \mathrm{SD}) 96.9 \pm 1.5 \%$ viable cells and $94.2 \pm 3.4 \%$ neutrophils. Concentrations of viable PMNL were adjusted to $4.0 \times 10^{6}$ viable neutrophils $/ \mathrm{mL}$ of HBSS.

Escherichia coli 487, originally isolated from a mammary gland of a cow with clinical mastitis, was the bacterial strain used for the bacterial phagocytosis assay. An overnight culture of E. coli 487 was prepared by inoculating $0.1 \mathrm{~mL}$ of stock culture into $12 \mathrm{~mL}$ of tryptic soy broth and incubating overnight in a gyratory shaker at $100 \mathrm{rpm}$ and $37^{\circ} \mathrm{C}$. The bacteria were then centrifuged (Sorvall RC-5B Refrigerated Superspeed Centrifuge, SS-34 rotor; DuPont Instruments, Wilmington, DE) for $20 \mathrm{~min}$ at $4^{\circ} \mathrm{C}$ and $5,049 \times g$. The pellet was resuspended into $12 \mathrm{~mL}$ of HBSS solution and diluted to a $70 \%$ transmission at $540 \mathrm{~nm}$ (Genesys 6 Spectrophotometer; Thermo Electron Corporation, Madison, WI), corresponding to approximately $8.0 \times$ $10^{6} \mathrm{cfu}$. Bacteria were serially diluted and spotted (10 $\mu \mathrm{L} \times 4$ ) on MacConkey (Becton Dickinson Microbiology Systems) agar plates and incubated at $37^{\circ} \mathrm{C}$ for 24 $\mathrm{h}$ to confirm the total count of $E$. coli. Bacteria were opsonized with $10 \%$ heat-inactivated bovine serum for 20 min at $20^{\circ} \mathrm{C}$ and placed on ice. Bovine serum used for opsonization was collected and pooled from 12 lactating cows.

Neutrophil assays were prepared in a 4:1 [average $( \pm \mathrm{SD}) 3.78 \pm 1.1: 1]$ bacteria-to-neutrophil ratio (Weiss and Hogan, 2005). Assays were completed in duplicate for each cow within each block. One milliliter of opsonized bacteria was mixed with $0.5 \mathrm{~mL}$ of neutrophil suspension in sterile $12 \times 75 \mathrm{~mm}$ culture tubes with closures. Assays were incubated at $37^{\circ} \mathrm{C}$ for $1.5 \mathrm{~h}$ at 100 rpm on a gyratory shaker. After incubation, samples were diluted $2: 1: 1$ as $50 \mu \mathrm{L}$ of assay suspension, 25 $\mu \mathrm{L}$ of acridine orange $(1.4 \mathrm{mg} / 10 \mathrm{~mL}$ of PBS, SigmaAldrich), and $25 \mu \mathrm{L}$ of crystal violet $(5 \mathrm{mg} / 10 \mathrm{~mL}$ of PBS, Fisher Scientific, Fair Lawn, NJ). Wet mount slides were prepared and the number of live (green bacterial cells) and dead (red bacterial cells) bacterial cells were counted for the first 25 neutrophils visible, using the $1,000 \times$ oil immersion lens under UV light (Nikon Fluorescence Microscope; Nikon Inc., Garden City, NY). Neutrophils were counted by moving the microscope stage left to right, and observation fields were not repeated. Neutrophil count was completed in duplicate for each cow within each block. Assays were completed within the same day for each individual block to minimize bacterial variability within each block. Assays were blinded so that the individual counting the neutrophils and bacteria had no knowledge of treatments and respective cows. Variables measured were percent neutrophils phagocytizing, neutrophil intracellular kill, and phagocytic index. Percent neutrophils phagocytizing was the number of neutrophils with internalized bacteria divided by the sum of neutrophils with internalized bacteria and neutrophils without internalized bacteria multiplied by 100. Neutrophil intracellular kill 
was the number of dead intracellular bacteria divided by the number of dead and live intracellular bacteria multiplied by 100 . Last, phagocytic index was the number of phagocytized bacteria divided by the number of neutrophils with internalized bacteria and neutrophils without internalized bacteria.

Six milliliters of blood was taken via tail vein on the first and last days of treatment period from each cow at approximately $5 \mathrm{~h}$ after feeding and centrifuged for 10 min at $4^{\circ} \mathrm{C}$ and $5,049 \times \mathrm{g}$. Serum was then removed in 1-mL aliquots and placed in plastic snap vials. Vials were frozen at $-20^{\circ} \mathrm{C}$ and stored until all serum samples were collected. Blood serum was sent to a commercial diagnostic laboratory (Diagnostic Center for Population and Animal Health, Lansing, MI) to be analyzed for trace mineral $(\mathrm{Cu}, \mathrm{Zn}$, and $\mathrm{Mn})$ concentrations in the blood. Elemental analysis was completed by methods of Wahlen et al. (2005). Trace mineral concentrations did not differ $(P>0.05)$ among groups the first day of the treatment period with mean $( \pm \mathrm{SD})$ serum concentrations for all cows, at $0.76 \pm 0.06 \mu \mathrm{g} / \mathrm{mL}, 1.30$ $\pm 0.09 \mu \mathrm{g} / \mathrm{mL}$, and $1.97 \pm 1.40 \mathrm{ng} / \mathrm{mL}$ for $\mathrm{Cu}, \mathrm{Zn}$, and $\mathrm{Mn}$, respectively.

Neutrophil function data and blood serum concentrations for $\mathrm{Cu}, \mathrm{Zn}$, and $\mathrm{Mn}$ were analyzed using least squares ANOVA. Models included the main effects of block and diet treatments. A priori comparison of treatments for neutrophil and blood serum data were (1) unsupplemented versus sulfate plus glycinate forms and (2) sulfate versus glycinate forms. Correlations among variables were determined using Pearson correlation coefficient. Statistical analyses were performed using the CORR, GLM procedures in SAS Version 9.4 (SAS Institute Inc., Cary, NC).
Dietary supplementation of $\mathrm{Cu}, \mathrm{Zn}$, and $\mathrm{Mn}$ via sulfate or glycinate forms for $30 \mathrm{~d}$ had no effect on percentage of neutrophils phagocytizing, intracellular kill, or phagocytic index (Table 3). Previous studies have shown varying effects of micronutrient supplementation of diets on bovine host defenses in cows during early or peak lactation. Scaletti et al. (2003) investigated neutrophil function of cows fed diets supplemented with $\mathrm{Cu}$ sulfate versus no supplemental $\mathrm{Cu}$. Coppersupplemented animals had lower bacterial counts in milk of challenged glands, as well as lower SCC and lower clinical udder scores than the unsupplemented animals after E. coli intramammary challenge. Nemec et al. (2012) investigated differences in neutrophil function between cows fed inorganic and organic sources of $\mathrm{Cu}, \mathrm{Mn}$, and $\mathrm{Zn}$. Similar to results of the current trial, Nemec et al. (2012) found no differences between inorganic and organic forms relating to neutrophil chemotaxis, phagocytosis, or oxidative burst. A primary difference in designs of the Scaletti et al. (2003) and Nemec et al. (2012) trials compared with the current study was the stage of lactation for experimental animals. Both of the previous trials used cows in early or peak lactation and the current study used late-lactation cows. Supplementation of micronutrients is often based on alleviation of the depression of host defenses related to decreases in DIM, decreases in micronutrient concentrations in blood, and the physiological changes related to micronutrient deficiencies occurring at parturition (reviewed by Overton and Yasui, 2014). In contrast, dietary supplementation with either sulfate or glycinate forms of $\mathrm{Cu}, \mathrm{Zn}$, and $\mathrm{Mn}$ did not affect blood concentrations of these minerals or in vitro blood neutrophil responses in late-lactation cows in the current trial.

Table 3. Contrast of in vitro neutrophil functions and blood mineral concentrations for cows fed (1) unsupplemented control diets compared with those fed diets supplemented with $\mathrm{Cu}, \mathrm{Zn}$, and $\mathrm{Mn}$ in sulfate and glycinate forms (Suppl) and (2) diets supplemented with $\mathrm{Cu}$, Zn, and Mn by either sulfate or glycinate forms

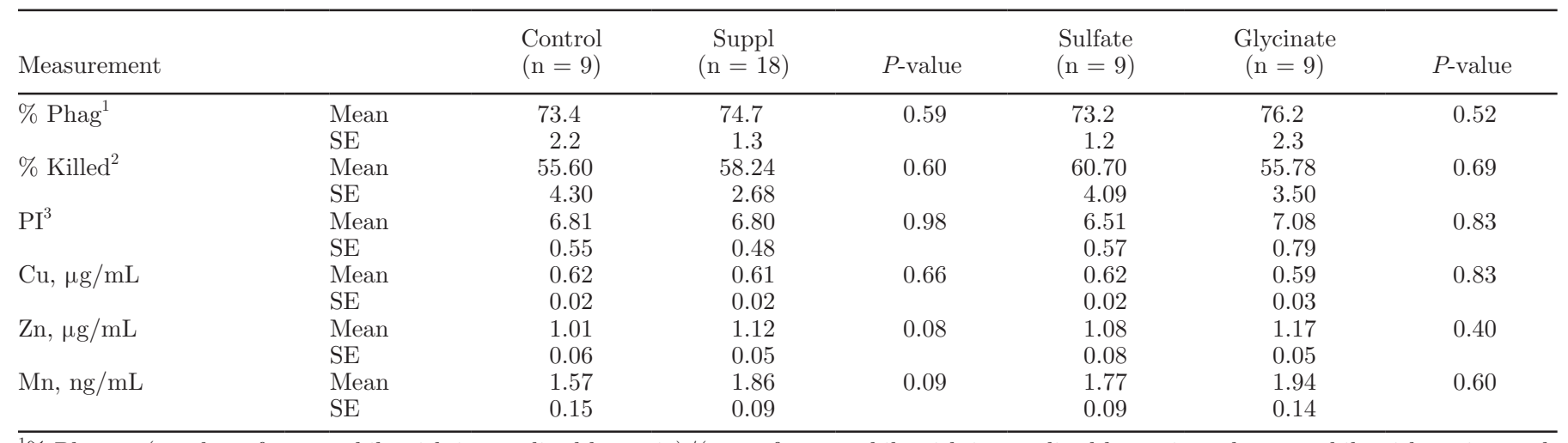

$\overline{1_{\%}}$ Phag $=$ (number of neutrophils with internalized bacteria)/(sum of neutrophils with internalized bacteria and neutrophils without internalized bacteria) $\times 100$.

${ }^{2} \%$ Killed $=($ number of dead intracellular bacteria $) /($ number of dead and live intracellular bacteria $) \times 100$.

${ }^{3} \mathrm{PI}=$ (number of phagocytized bacteria)/(number of neutrophils with internalized bacteria and neutrophils without internalized bacteria). 
Differences in bovine neutrophil function related to supplementation of micronutrients in diets of dairy cows have been demonstrated using the assays employed in the current study (Grasso et al., 1990; Hogan et al., 1990, 1992). Each of these trials reported supplementation of diets or parental injection of Se, vitamin E, or both Se and vitamin E increased intracellular kill of bacteria by neutrophils but had no effect on phagocytic ability of neutrophils. Weiss and Hogan (2005) also investigated neutrophil function differences between cows fed inorganic and organic sources of Se. Neutrophils from cows fed either selenate or Se-yeast supplemented diets did not differ regarding phagocytosis or intracellular kill.

In previous trials intracellular kill by neutrophils was related to the blood concentrations of the micronutrients being tested (Hogan et al., 1990, 1992). However, in the current trial, blood serum concentrations for $\mathrm{Cu}$, $\mathrm{Zn}$, and Mn were not correlated with neutrophil function and did not differ among treatments after $30 \mathrm{~d}$ on experimental diets (Table 3). Pearson correlation coefficients between serum mineral concentrations and neutrophil functions on day of neutrophil collection ranged from $-0.20(P=0.2)$ between serum $\mathrm{Mn}$ and phagocytic index to $0.09(P=0.63)$ between serum $\mathrm{Cu}$ and percentage intracellular kill of bacteria. Normal range for serum $\mathrm{Cu}$ is 0.6 to $1.1 \mu \mathrm{g} / \mathrm{mL}$ and serum $\mathrm{Zn}$ is 0.6 to $1.9 \mu \mathrm{g} / \mathrm{mL}$ (Herdt and Hoff, 2011). Manganese reference values were estimated as 0.9 to $6.0 \mathrm{ng} / \mathrm{mL}$ (Herdt and Hoff, 2011). In the current trial, serum concentrations fell within these normal ranges for $\mathrm{Cu}, \mathrm{Zn}$, and $\mathrm{Mn}$ in cows fed unsupplemented and supplemented diets. Previous studies found similar results regarding the relationship of unchanging plasma mineral concentrations and neutrophil function when fed organic $\mathrm{Cu}$ or Zn (Nemec et al., 2012). Blood concentrations of micronutrients are frequently used in assessment of mineral status of the cow because blood concentrations of minerals are significantly correlated with nutritional status of some trace elements and are more reliable than assessing mineral status from diet evaluation (Herdt and Hoff, 2011).

The lack of change in serum mineral concentrations in the current study during the treatment period may explain the observed similarity among treatments in neutrophil function. Serum concentrations for $\mathrm{Cu}, \mathrm{Zn}$, and $\mathrm{Mn}$ did not differ among treatments. If no differences were observed among serum values, differences in neutrophil function among treatments were unlikely. Blood values (whole blood, plasma, or serum) for trace minerals are important to measure because they reflect mineral status of transport pools and directly influence mineral availability to neutrophils and other circulating leukocytes. Neutrophils presumably come in contact and obtaining necessary trace minerals via blood as they are circulating (Leitch et al., 2009). This is especially true for minerals that do not have permeant stores in tissue, such as Zn and Mn. Although cows in the unsupplemented group had a 60-d depletion period, blood values of unsupplemented cows did not differ from those supplemented and were within normal ranges. With no differences among control and supplemented cows in the current study, $60 \mathrm{~d}$ during late lactation may not have been long enough to observe differences in serum concentrations for $\mathrm{Cu}, \mathrm{Zn}$, and $\mathrm{Mn}$ or in vitro neutrophil function. Blood values of $\mathrm{Cu}, \mathrm{Zn}$, and $\mathrm{Mn}$ indicated the control diet alone was sufficient to maintain adequate concentrations of these minerals for $90 \mathrm{~d}$ in late-lactation cows. Blood concentrations of minerals associated with bovine neutrophil function often decrease during the late gestation and periparturient period (Overton and Yasui, 2014). Previous trials determining a positive role of dietary supplementation $\mathrm{Cu}$ in improving neutrophil function and reducing mastitis were conducted with cows fed different diets throughout the nonlactating period and early lactation (Scaletti et al., 2003; Siciliano-Jones et al., 2008; Scaletti and Harmon, 2012). The use of latelactation cows in the current trial may have influenced the effects of dietary supplementation on blood concentrations and neutrophil function differently compared with earlier trials. Although the current trial did not compare cows among different stages of lactation, continued supplementation of $\mathrm{Cu}, \mathrm{Zn}$, and $\mathrm{Mn}$ during late lactation at concentrations effective at parturition and early lactation may not be warranted.

\section{REFERENCES}

Andrieu, S. 2008. Is there a role for organic trace element supplements in transition cow health? Vet. J. 176:77-83.

Carlson, G. P., and J. J. Kaneko. 1973. Isolation of leukocytes from bovine peripheral blood. Proc. Soc. Exp. Biol. Med. 142:853-856.

Goff, J. P. 2006. Major advances in our understanding of nutritional influences on bovine health. J. Dairy Sci. 89:1292-1301.

Grasso, P. J., R. W. Scholz, R. J. Erskine, and R. J. Eberhart. 1990. Phagocytosis, bacterial activity and oxidative metabolism of mammary neutrophils from dairy cows fed selenium-adequate and selenium-deficient diets. Am. J. Vet. Res. 51:269-274.

Heinrichs, A. J., S. S. Costello, and C. M. Jones. 2009. Control of heifer mastitis by nutrition. Vet. Microbiol. 134:172-176.

Herdt, T. H., and B. Hoff. 2011. The use of blood analysis to evaluate trace mineral status in ruminant livestock. Vet. Clin. North Am. Food Anim. Pract. 27:255-283.

Hogan, J. S., K. L. Smith, W. P. Weiss, D. A. Todhunter, and W. L. Schockey. 1990. Relationships among vitamin E, selenium, and bovine blood neutrophils. J. Dairy Sci. 73:2372-2378.

Hogan, J. S., W. P. Weiss, D. A. Todhunter, and K. L. Smith. 1992. Bovine neutrophil responses to parenteral vitamin E. J. Dairy Sci. 75:399-405. 
Leitch, J. M., P. J. Yick, and V. C. Culotta. 2009. The right to choose: Multiple pathways for activating copper, zinc superoxide dismutase. J. Biol. Chem. 284:24679-24683.

Nemec, L. M., J. D. Richards, C. A. Atwell, D. E. Diaz, G. I. Zanton, and T. F. Gressley. 2012. Immune responses in lactating Holstein cows supplemented with $\mathrm{Cu}, \mathrm{Mn}$, and $\mathrm{Zn}$ as sulfates or methionine hydroxyl analogue chelates. J. Dairy Sci. 95:4568-4577.

Nocek, J. E., M. T. Socha, and D. J. Tomlinson. 2006. The effect of trace mineral fortification level and source on performance of dairy cattle. J. Dairy Sci. 89:2679-2693.

Overton, T. R., and T. Yasui. 2014. Practical applications of trace minerals for dairy cattle. J. Anim. Sci. 92:416-426.

Scaletti, R. W., and R. J. Harmon. 2012. Effect of dietary copper source on response to coliform mastitis in dairy cows. J. Dairy Sci. 95:654-662.
Scaletti, R. W., D. S. Trammell, B. A. Smith, and R. J. Harmon. 2003. Role of dietary copper in enhancing resistance to Escherichia coli mastitis. J. Dairy Sci. 86:1240-1249.

Siciliano-Jones, J. L., M. T. Socha, D. J. Tomlinson, and J. M. DeFrain. 2008. Effect of trace mineral source on lactation performance, claw integrity, and fertility of dairy cattle. J. Dairy Sci. 91:1985-1995.

Wahlen, R., L. Evans, J. Turner, and R. Hearn. 2005. The use of collision/reaction cell ICP-MS for the determination of elements in blood and serum samples. Spectroscopy (Springf.) 20:84-89.

Weiss, W. P., and J. S. Hogan. 2005. Effect of selenium source on selenium status, neutrophil function, and response to intramammary endotoxin challenge of dairy cows. J. Dairy Sci. 88:4366-4374. 